\title{
Library Programs and Special Libraries ${ }^{1}$
}

\author{
Ray M. Fry
}

Although most of the programs administered in my Office primarily benefit public and academic libraries*, several of our programs can significantly benefit special libraries and school libraries. I do realize also that many of the libraries represented in the Education Division are in academic libraries. Of course, in this day of electronic resource-sharing, strengthening any library of any type that is connected to a major network such as the Internet strengthens all libraries of any and every type that are also connected to the Internet.

The programs we administer are all, with one exception, authorized by the Higher Education Act and the Library Services and Construction Act (LSCA). Three of the prograuns are state formula programs and the other six are discretionary programs. States apply to the Department formula grant funds which they then administer. Libraries and other eligible entities apply directly to the Department for discretionary grant funds. State formula programs are administered by the state library agencies, and the discretionary programs are administered directly between my office and libraries and other eligible institutions or agencies.

The one state formula program that can strengthen all types of libraries is the LCSA Title III program which establishes and maintains cooperative activities among all ty pesof libraries. Any project to be eligible for funding must involve at least two types of libraries. You should know this program and what it can do for your library. Contact your state library agency to find out how you can participate in this effort. Since the mid sixties, approximately one quarter of a billion dollars have gone into this progran. Today more than half of the state agencies have Internet-related projects funded under Title III.

Only public libraries are eligible for Title I (Services) and Title II (Contruction) funds under LSCA. Public and state library agencies are the eligible recipients for LSCA Title VI (Literacy) funds. Recognized Indian Tribes and Hawaiian Natives arc eligible for grants to improve public library services under LSCA Title IV programs. However, as I have just stated, stronger public libraries can, through networking, benefit all types of libraries.

Under the Higher Education Act (HEA), Title II-A, the college technology program, and Title II-C, the strengthening research libraries programs support academic and research libraries.

The one HEA program that you should give special attention to is the HEA II-B training program, both the fellowship and institute components. We have just announced 18 new doctoral fellowships and 47 masters. A list of these fellowships is at the back of the room. These fellowships are in addition to the approximately 100 continuing doctorates. Priority at the doctoral level is given to students who want to teach in schools of library and information science.

We will be announcing soon grant awards of $\$ 1.5$ million for institutes to retrain librarians in support of the education reform movement and the National Information Infrastructure.

If you have interest in either the institutes or fellowships consult the library schools receiving the awards. Institutions receiving the grants have sole authority for selecting the participants.

In March of this year the President signed into law the "Goals 200: Educate America Act" which, in addition to formalizing the educational reform movement, reauthorizes the Of fice of Educational Research and Improvement. Under the "new OERI five National Research Institutes, an Office of Educational Reform and Dissemination, and a National Library of Education (NLE) have been created.

The NLE is to become a "central location within the federal government for information about education." Later this year a national search will be undertaken to recruit a director for the NLE. The law stipulates the formation of a "Task Force" to assist in the planning of the NLE.

The Department of Education will announce in August or September the funding of one of the most significant projects the Office of Library Programs has initiated in several decades. It is an assessment of the role of school and public libraries in supporting the education reform movement. The stimulusfor the project grew out of a seminar at the University of California at Berkeley entitled "Libraries and the Learning Society" sponsored by the U.S. Department of Education. Alliance for Excellence: Librarians Respond to "ANational At Risk" contained the recommendation growing out of the Berkeley Seminar.

In closing, I would like to comment quickly on the efforts al ready underway in the library world and soon to be launched by the Department, to reauthorize LSCA.

The Department is pleased to see the interest in the National Education Goals, at-risk youth, and the National Information Infrastructure that is rejected in the American Libary Association Task Force's recommendations on the reauthorization of LSCA. In addition to those areas of concern, we believe there is great

${ }^{1}$ The following is the actual text of a presentation made at the Special L.ibaries Asscriation 85th Annual Conference. Atlanta, June 1994. 
need for professional development.

You should be concerned with this reauthorization. Undoubtedly there will be programs that can benefit your libraries. I would urge you to get involved and to be especially alert to the resourcesharing potential and to the opportunities for profesional development.

We are so busy with our ongoing responsibilities that we seldom stop to think of "what weare all about." When Diane Ravitch was still our Assistant Secretary in OERI, she told the directors at a weekly meeting that if she had only three words to express her vision or OERI those three words would be "All Kids Learning." She then tossed the ball to us saying "what is your vision to match my vision?" Since I was second in line to "report my vision," I had three to five minutes to think. I said my vision to match your vision, "All Kids Learning," would be that "All Libraries as Dynamic Learning Centers supporting a Nation of Students."

* Since this speech was given the HEA Title II-A College Library Technology and Cooperation Grants Program and the HEA Title II-C Improving Access to Research Library Resources Program have been phased out. 